\title{
Day Times Microgram per Milliliter
}

National Cancer Institute

\section{Source}

National Cancer Institute. Day Times Microgram per Milliliter. NCI Thesaurus. Code C85586.

Days times micrograms per milliliter. 